\title{
Geometry and thermal regime of the King George Island ice cap, Antarctica, from GPR and GPS
}

\author{
Norbert BLINDOW, ${ }^{1 *}$ Sonja K. SUCKRO, ${ }^{1}$ Martin RÜCKAMP, ${ }^{1}$ Matthias BRAUN, ${ }^{2}$ \\ Marion SCHINDLER, ${ }^{1 \dagger}$ Birgit BREUER, ${ }^{1}$ Helmut SAURER, ${ }^{3}$ Jefferson C. SIMÕES, ${ }^{4}$ \\ Manfred A. LANGE ${ }^{1 \ddagger}$ \\ ${ }^{1}$ Institute for Geophysics, University of Münster, Corrensstrasse 24, D-48149 Münster, Germany \\ E-mail: norbert.blindow@bgr.de \\ ${ }^{2}$ Center for Remote Sensing of Land Surfaces, University of Bonn, Walter-Flex-Strasse 3, D-53113 Bonn, Germany \\ ${ }^{3}$ Department of Physical Geography, University of Freiburg, Werthmannstrasse 4, D-79085 Freiburg, Germany \\ ${ }^{4}$ NUPAC, Universidade Federal do Rio Grande do Sul, Av. Bento Gonçalves 9500, 91501-970 Porto Alegre, RS, Brazil
}

\begin{abstract}
King George Island is the largest of the South Shetland Islands, close to the tip of the Antarctic Peninsula. The annual mean temperature on the island has increased by $1^{\circ} \mathrm{C}$ during the past three decades, and the ice cap that covers the majority of the island is sensitive to climatic change. We present data from two field campaigns (1997 and 2007): $700 \mathrm{~km}$ of global positioning system (GPS) and ground-penetrating radar (GPR) profiles were collected on Arctowski Icefield and on the adjacent central part. The data were analysed to determine the surface and bed topography and the thermal regime of the ice. Average ice thickness is $250 \mathrm{~m}$ and maximum thickness is $420 \mathrm{~m}$. The GPR profiles show isochrones throughout the ice cap which depict the uparching of Raymond bumps beneath or close to the ice divides. A water table from percolation of meltwater in the snowpack shows the firn-ice boundary at $\sim 35 \mathrm{~m}$ depth. The firn layer may be temperate due to the release of latent heat. In the area below $400 \mathrm{~m}$ a.s.l., backscatter by water inclusions is abundant for ice depths below the water table. We interpret this as evidence for temperate ice. Scatter decreases significantly above $400 \mathrm{~m}$. Ice temperatures below the water table in this part of the ice cap are subject to further field and modelling investigations.
\end{abstract}

\section{INTRODUCTION}

Cold ice sheets with temperatures below pressure-melting point and negligible amounts of meltwater (not affecting the ice flow) are distinguished from usually smaller and temperate ice caps (temperatures at pressure-melting point) where meltwater is present within the ice body (Paterson, 1994).

An example of the latter are the ice caps of the subAntarctic islands which have been subject to increasing surface temperatures over the last few decades (Turner and others, 2005). King George Island (KGl), the largest of the South Shetland Islands, is located in the marginal sea-ice zone north of the Antarctic Peninsula at $62^{\circ} \mathrm{S}, 58^{\circ} \mathrm{W}$ and is influenced by subpolar maritime climate conditions (Fig. 1).

The high number of permanent research stations and a gravel runway on the ice-free Fildes Peninsula reflect the good accessibility of KGI, making it an ideal place to study the effects of atmospheric warming on small ice caps within a maritime climate. Wen and others (1998) state that the mean annual temperature at sea level is $-2.4^{\circ} \mathrm{C}$, that the firn is temperate at altitudes above $380 \mathrm{~m}$ and that substantial percolation takes place in the firn forming ice lenses (see also Simões and others, 2004).

\footnotetext{
*Present address: Federal Institute for Geosciences and Natural Resources (BGR), Stillweg 2, D-30655 Hannover, Germany.

$\dagger$ Maiden name: Marion Pfender; present address: Bestec $\mathrm{GmbH}$, Oskarvon-Miller-Strasse 2, D-76829 Landau, Germany.

¥Present address: Energy, Environment and Water Research Center (EEWRC), The Cyprus Institute, PO Box 27456, CY-1645 Nicosia, Cyprus.
}

Simões and others (1999) identify 70 drainage basins in the $1250 \mathrm{~km}^{2} \mathrm{KGl}$ ice cap where several southeast ice fronts have retreated rapidly since the late 1950s, some by more than $1 \mathrm{~km}$. Despite the ideal logistical situation of KGI, little research has been carried out regarding determination of ice thickness and the geometries of surface and bedrock. Previous radio-echo sounding was restricted to a narrow corridor from Bellingshausen Dome along the main ice divide to the Main Dome. The results were ambiguous and suffered from absorption and scattering (Govorukha and others, 1975; Simões and Bremer, 1995; Macheret and Moskalevsky, 1999; Travassos and Simões, 2004).

Data used for this paper were collected during a BrazilianGerman expedition in 1997/98 by teams from the University of Münster (UM), the University of Freiburg (UF) and NUPAC (Nucléo de Pesquisas Antárticas e Climáticas) in 1999/2000 and by UM and the University of Bonn (UB) in 2004/05. The investigated area was extended in 2007 by a German expedition from UM and UB with the aim of completing the geometry and surface movement data (for the latter see Rückamp and others, 2010).

The investigated area, campsites, locations and profile lines are shown in Figure 2. Results from single-location surface energy-balance computations based on readings from automatic weather stations (AWSs) located in different altitudes in the study area are given by Braun and others (2001, 2004).

Spatially distributed melt modelling was carried out based on the 1997/98 AWS dataset by Braun and Hock (2004). The results showed the impact of the distinct atmospheric circulation patterns on melt rates. Considerable surface melt was 


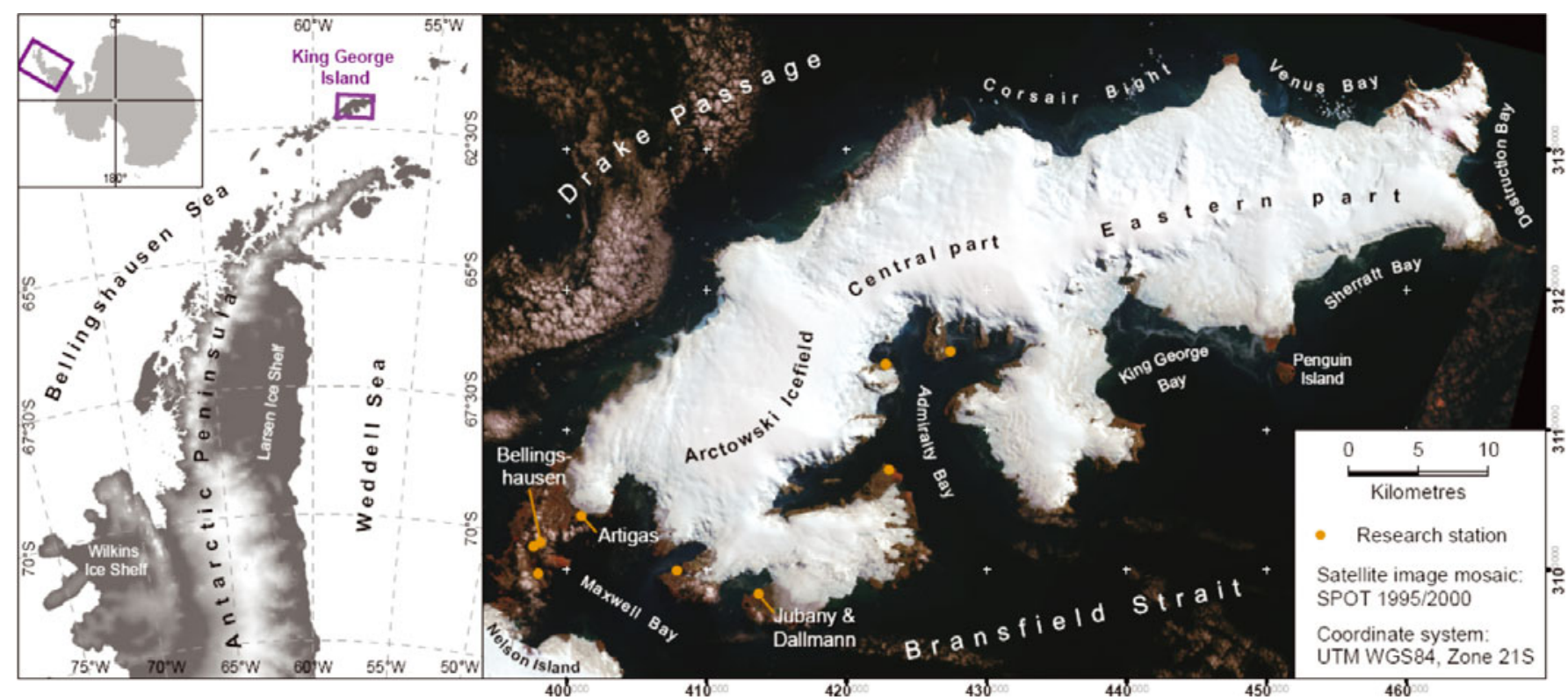

Fig. 1. Location of King George Island. Left: map prepared from Antarctic Digital Database (ADD) and RADARSAT Antarctic Mapping Project (RAMP) data; right: courtesy of SPOT Image 1995/2000.

observed and modelled for December January of 1997/98 and 1999/2000 up to the highest elevations of the KGI ice cap. A firn profile at about 619 ma.s.l. instrumented with thermistor strings in 1999/2000 showed a $10 \mathrm{~m}$ firn temperature of about $-0.3^{\circ} \mathrm{C}$. The winter cold content of the surface snowpack, still observable in early December, was continuously filled by percolating meltwater during subsequent weeks.

Since the melt period of KGl extends into March/April, considerable meltwater percolation, even to deeper layers of the snowpack, has to be expected. This confirms the findings of a water table and the problems of water intrusion in the borehole of an earlier ice-coring attempt in 1995/96 (Simões and others, 2004) at $62^{\circ} 07^{\prime} \mathrm{S}, 58^{\circ} 37^{\prime} \mathrm{W}$ (690 ma.s.I.). Simões and others (2004) also reported a snow-ice transition

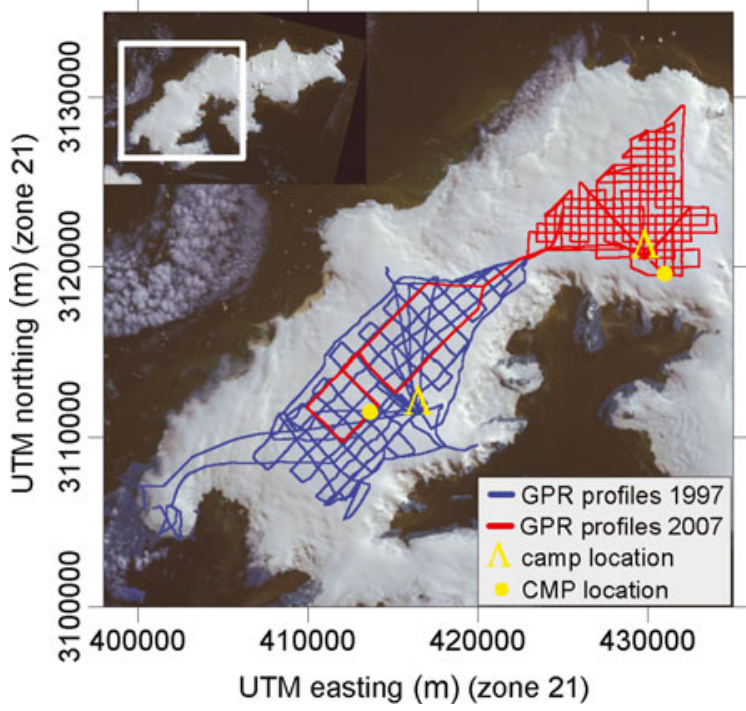

Fig. 2. GPR profiles, locations of camps and common midpoints (CMPs) in the 1997 and 2007 field campaigns. Background image: SPOT satellite image mosaic (courtesy of Eurimage 1995/2000). at $35 \mathrm{~m}$ and a borehole temperature of -0.35 to $-0.25^{\circ} \mathrm{C}$ at $45 \mathrm{~m}$ depth, still slightly below pressure-melting point.

Helicopter-borne measurements to cover the crevassed areas were planned during several seasons, but could only be accomplished in the austral summer of 2009 and cannot yet be integrated here.

We provide a summary of the results of ground-penetrating radar (GPR) and differential global positioning system (DGPS) measurements of the geometry, internal structures and thermal regime of the KGI ice cap.

\section{INSTRUMENTS}

\subsection{Choice of GPR centre frequency}

Temperate ice usually contains inhomogeneities such as water pockets and ducts which may cause heavy scattering of electromagnetic waves of comparable wavelengths (Rayleigh and Mie scattering). Normally this is overcome by utilizing low-frequency radars (of a few megahertz with wavelengths in ice of up to $100 \mathrm{~m}$ ) which usually suppress scattering effects and show a distinct bedrock reflection.

Scattered energy can be focused by geophysical data processing, namely the process of migration. This technique was developed to process reflected seismic data. Lateral and vertical resolution may be increased significantly and scattering effects are compressed. Blindow and Thyssen (1986) carried out the first successful soundings of temperate ice at $30 \mathrm{MHz}$ centre frequency (wavelength in ice is $6 \mathrm{~m}$ ), with subsequent computerized migration as a processing tool.

\subsection{Field campaign, 1997}

The GPR equipment used was the Münster monopulse GPR system as described by Blindow (1994). A major change was applied with respect to the antenna system: it utilized a shielded broadband antenna with $50 \mathrm{MHz}$ centre frequency similar to the design discussed in Eibert and others (1997).

The DGPS equipment consisted of four Magellan ProMark X-CM receivers. The same models were used for the 2004/05 measurements. 


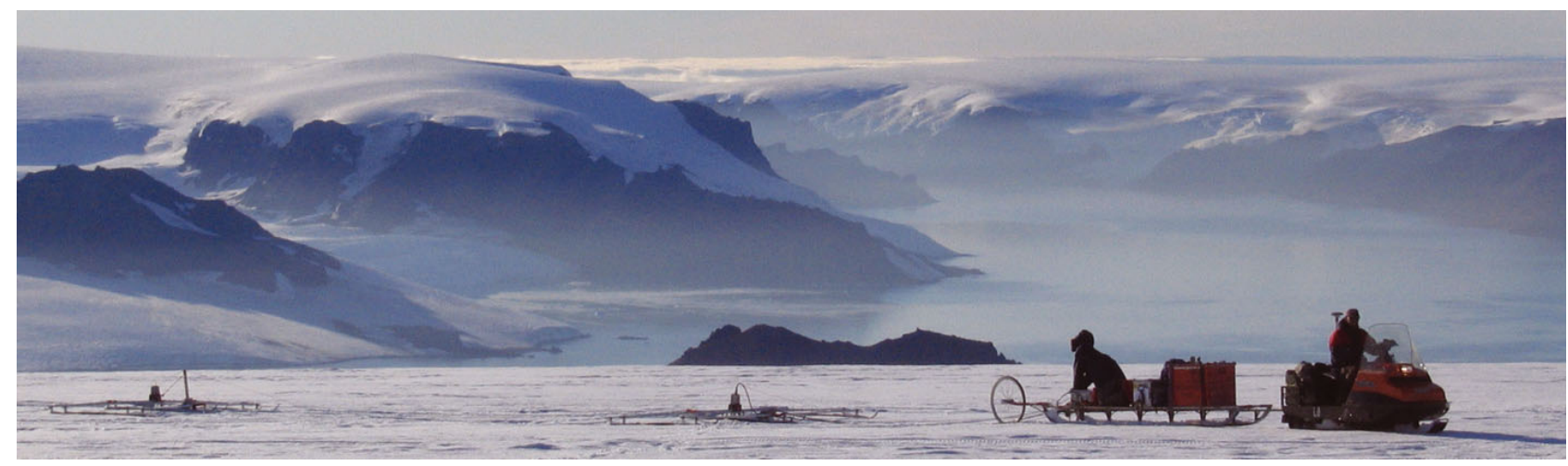

Fig. 3. The GPR antennae and a sledge with the GPR control unit are dragged by a snowmobile with a DGPS system.

\subsection{Field campaign, 2007}

The GPR equipment comprised a commercial SIR-3000 console with a DA769 receiving unit of Geophysical Survey Systems Inc. (GSSI) and a $1 \mathrm{kV}$ metal-oxide semiconductor field-effect transmitter (MOSFET) triggered via a fibre-optic link (constructed by the University of Münster). The antennae with a centre frequency of $25 \mathrm{MHz}$ were combinations of folded broadband dipoles (Peters and Young, 1986) and resistively loaded dipoles (Wu and King, 1965).

The DGPS equipment consisted of four dual frequency receivers in two pairs of NovAtel DL4 and Trimble 4000 SSE. The set-up used in the field is shown in Figure 3.

\section{GPR MEASUREMENTS}

\subsection{CMP measurements}

In both field campaigns, common-midpoint (CMP) measurements were performed to determine the velocities of the radar signals in the subsurface. The locations of the CMPs are depicted in Figure 2; the 1997 CMP was located $607 \mathrm{~m}$ a.s.l. and the $2007 \mathrm{CMP}$ at $620 \mathrm{~m}$ a.s. I. Figure 4 depicts the velocity adaption of a three-layer model to the 2007 data as determined with the ReflexW program (K.J. Sandmeier software). Hyperbola reflections are caused by the water table, isochrones and the bedrock. The 1997 data resulted in a two-layer model based on the water table and bedrock reflections.

The models are very similar, with average velocities in the firn layer of 0.194 and $0.193 \mathrm{~m} \mathrm{~ns}^{-1}$. In the two-layer model, a velocity of $0.168 \mathrm{~m} \mathrm{~ns}^{-1}$ is proposed for the ice between the water table and bedrock. The three-layer model has an additional layer with $0.175 \mathrm{~m} \mathrm{~ns}^{-1}$ between the water table and $80 \mathrm{~m}$ depth, until reaching $0.168 \mathrm{~m} \mathrm{~ns}^{-1}$. The variability of firn thickness with altitude introduces uncertainty in the estimated velocities, and we estimate the best accuracy to be $\pm 1.7 \%$.

\subsection{GPR profiles}

The radar data were processed in several steps (at $25 \mathrm{MHz}$ centre frequency) comprising a time-zero correction corresponding to the antenna offset, a frequency domain bandpass filter from 17 to $80 \mathrm{MHz}$ and a despiking filter. The direct signal was reduced to enhance the water table reflection. Time-domain migration (diffraction stack) with a single velocity was used to collapse diffraction hyperbolas and to recover the actual dip of reflectors (which is true only in the case of a two-dimensional (2-D) geometry or point diffractors). Finally, to account for dielectric losses in the temperate ice, a gain of $0.08 \mathrm{~dB} \mathrm{~m}^{-1}$ was applied.

A typical example of the processed radar data obtained near the ice divide can be seen in Figure 5. For easier interpretation, the profile is vertically exaggerated and topographically corrected. A strong reflection marks the water table at an average depth of $35 \mathrm{~m}$, which indicates the firn-ice boundary. Layering inside the ice is visible by isochrones, which are arching up near the ice divide. These arches are patterns of ice dynamics called Raymond bumps (Raymond, 1983). The irregular reflections at the bottom of the radargram are caused by the ice-bedrock interface.

\subsection{Thermal regime from interpretation of GPR data}

The spatial distribution of internal features was studied in detail using the 1997/98 dataset. The results can also be extrapolated and verified in other parts of the KGI ice cap. Water inclusions are seen in the radargrams as small

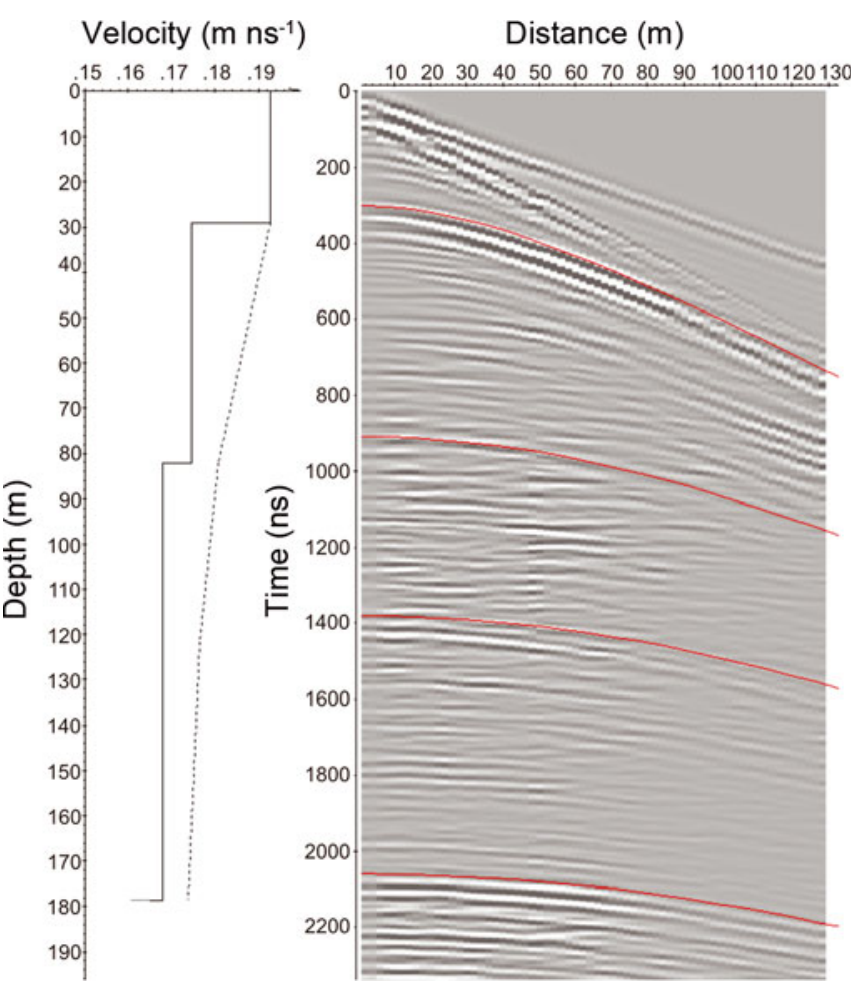

Fig. 4. CMP analysis: velocity-depth model and processed data. 


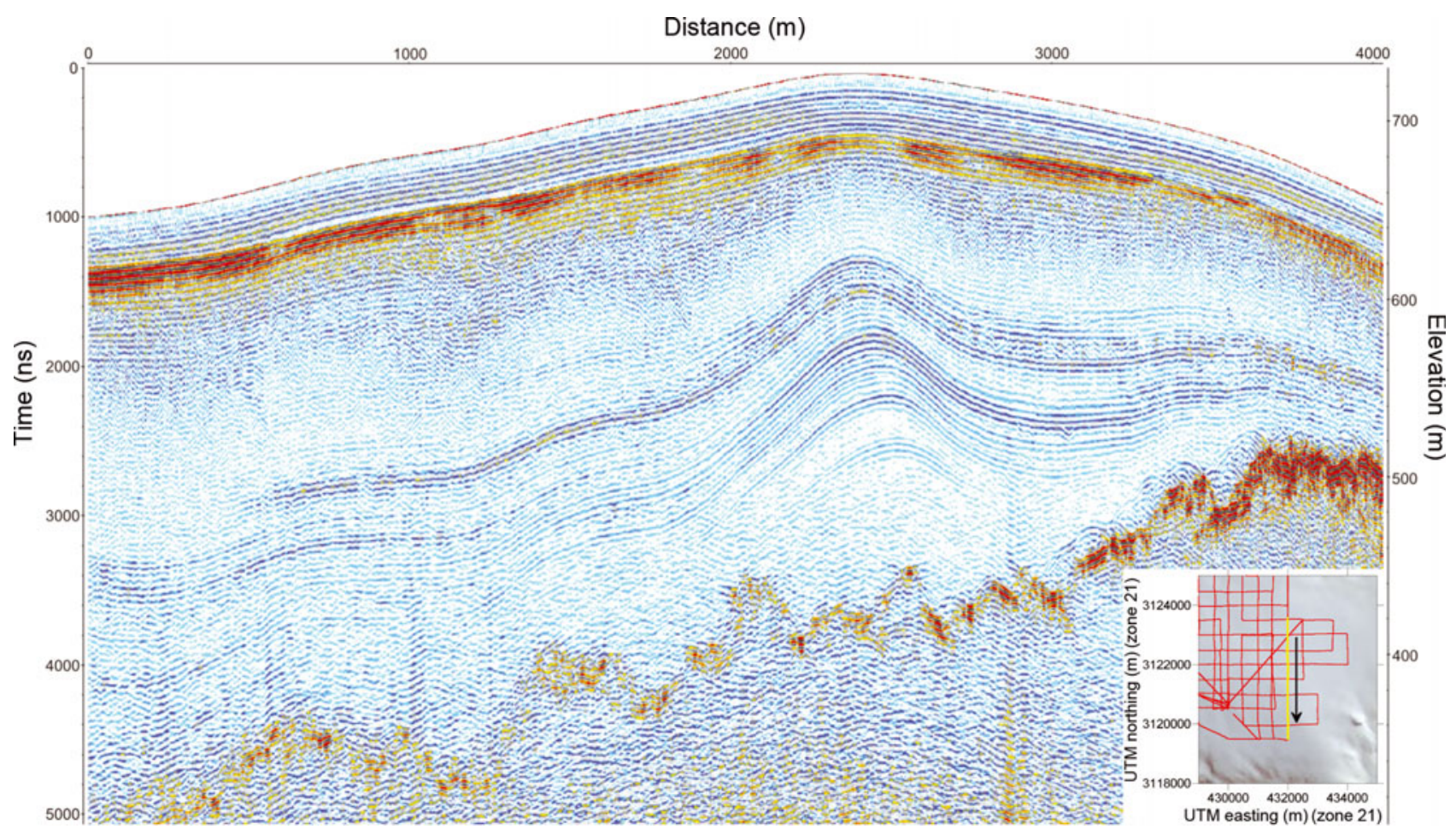

Fig. 5. Typical radargram near the ice divide showing a water table at 600-650 m a.s.l., bedrock in red at 300-500 m a.s.I. and uparching of isochrones starting at $550 \mathrm{~m}$ a.s.l. (right-hand side).

hyperbolic diffraction features. Some single-point diffractors, possibly caused by water-filled ducts or voids, and a strong reflection of the water table are present almost throughout the ice cap. Diffraction features are abundant in areas of surface elevation below $400 \mathrm{~m}$ a.s.I. but are scarce or absent in areas above that. We used the abundance of diffractions (high backscatter) as an indication for temperate ice caused by liquid water content. This method of discriminating cold and temperate ice in alpine glaciers was also used by Eisen and others (2009).

It is noted that radar backscatter vanishes on the few profiles below the equilibrium line (at $160 \mathrm{~m}$ a.s.l. in 1991/92) which are cold according to Wen and others (1998).

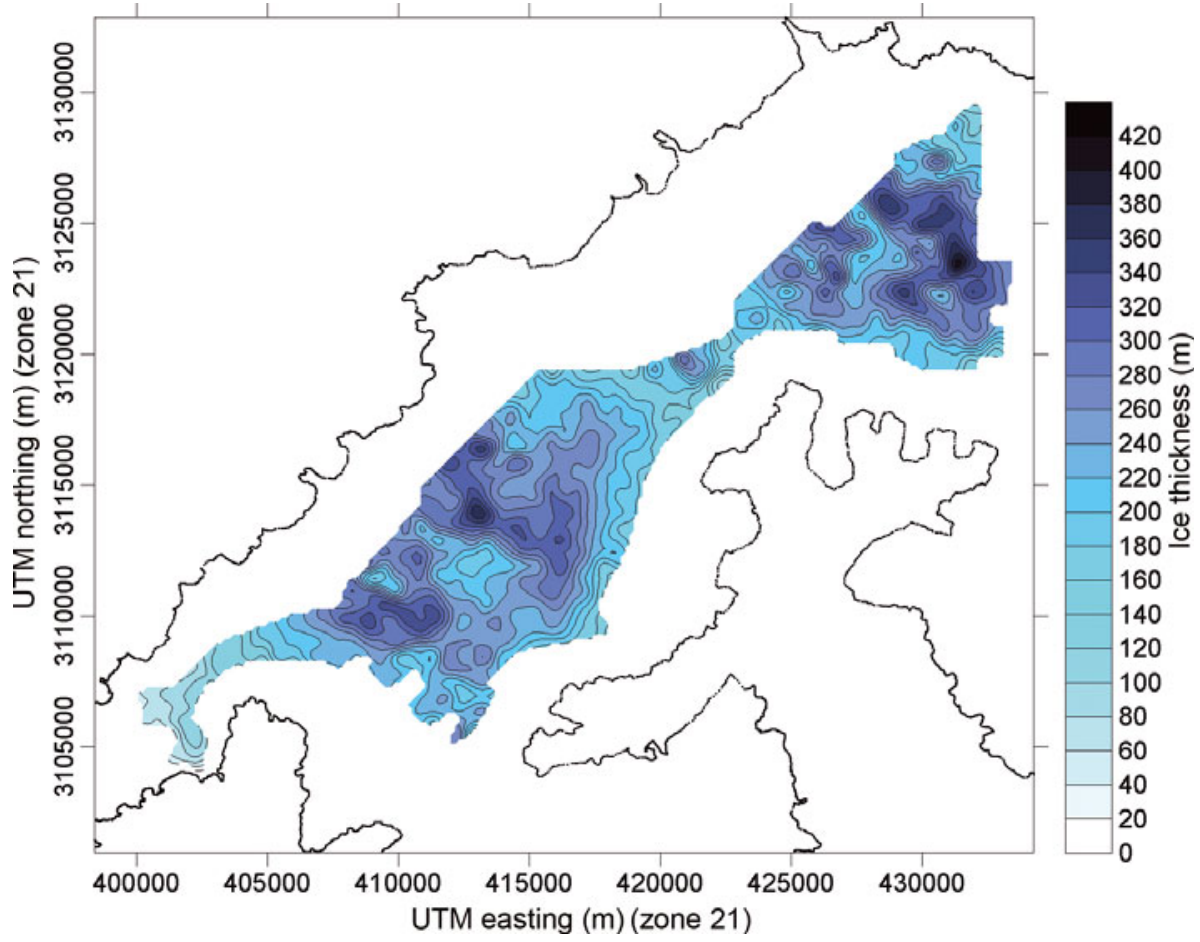

Fig. 6. Ice thickness in the surveyed area on KGI. 

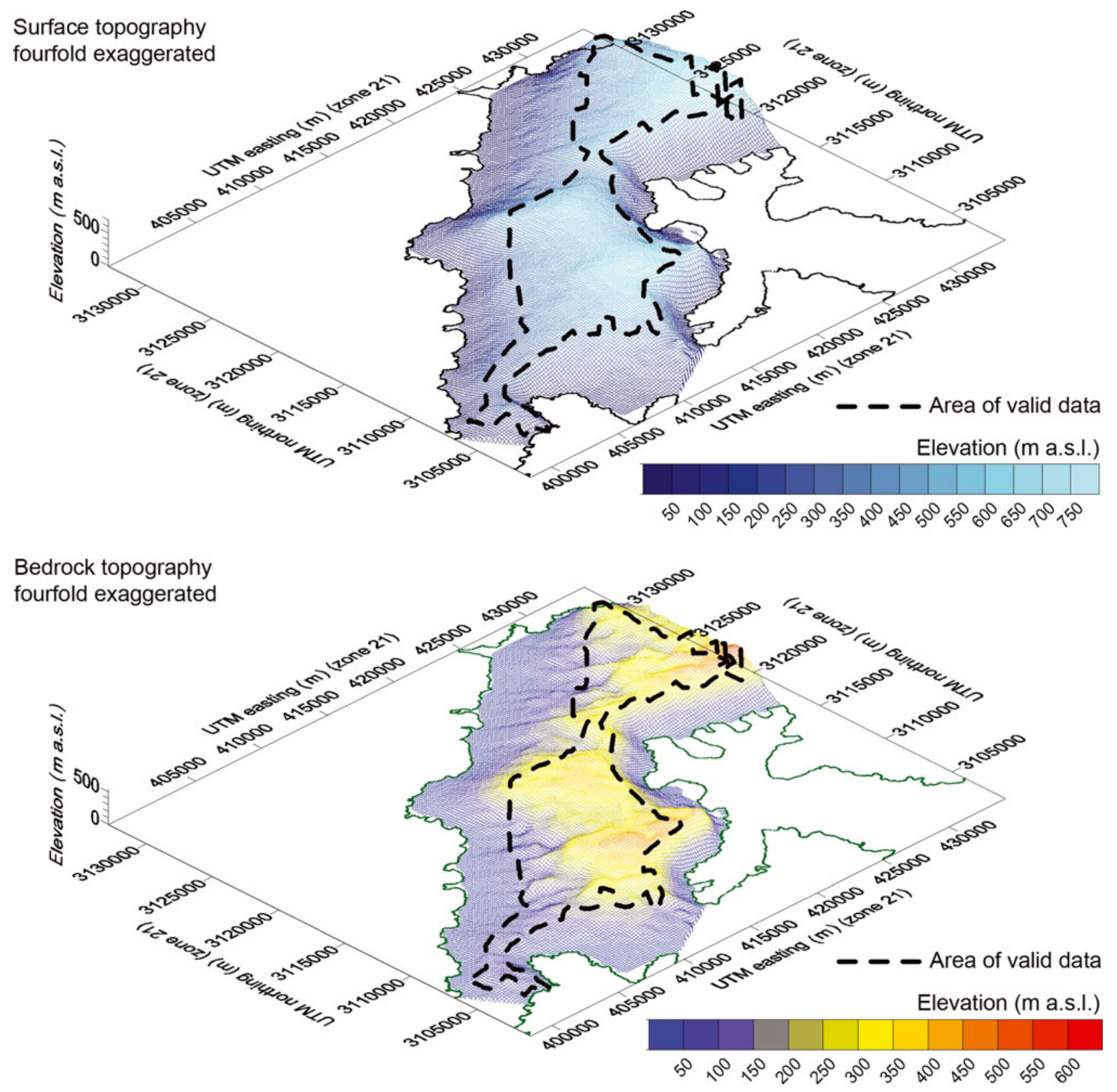

Fig. 7. Surface and bedrock topography of the western part of KGI.

\section{TOPOGRAPHICAL RESULTS}

Surface and bedrock topographies were generated by merging the datasets. The coastline was added with values of $0 \mathrm{~m}$ for the surface elevation, and ice-thickness and bedrock elevation data were also combined.

The accuracy of surface topography is estimated from the GPS accuracies. The vertical accuracy of singlefrequency DGPS in kinematic mode is $1.6 \mathrm{~m}$ and a few centimetres in static mode. The vertical accuracy of dualfrequency systems is usually in the centimetre range. Due to vertical displacements of the base station and other effects, we estimate a vertical error of $0.2 \mathrm{~m}$ for kinematic measurements. Ice-thickness accuracy varies from about $2 \mathrm{~m}$ in areas with a smooth bed to about $10 \mathrm{~m}$ in areas with a rough or undulating bed.

These topography data were gridded with Surfer (Golden Software, Inc.), using the kriging algorithm on a $500 \mathrm{~m}$ grid. To include the area between the outer profiles and the coast, the radius for kriging was set to $10 \mathrm{~km}$. To smooth the contours, two nodes were inserted between the lines by the spline smooth function.

\subsection{Ice thickness map}

Figure 6 shows the ice thickness in the surveyed area without the interpolated margins. The mean ice thickness along the profiles is $250 \mathrm{~m}$, with a maximum of $422 \mathrm{~m}$ in the eastern part of the central ice cap. Some southeast-northwest areas of thick ice indicate the main drainage valleys of the ice cap. This can also be seen in the bedrock topography as described in section 4.2.

\subsection{Surface and bedrock topography}

Three-dimensional (3-D) models of the surface and bedrock topography are depicted in Figure 7 . These were generated as described previously, including the interpolated margin between the GPR profiles and the coastline. The surface of 
the ice cap rises slowly from the northwest coast to the ice divide, while the southeast slope is much steeper. Two main domes dominate Arctowski Icefield, while the highest dome (706 m a.s.l.) lies in the central part.

The bedrock topography exhibits the same difference in slope as can be seen in the surface topography, with a steep slope to Admiralty Bay. Steep valleys are carved into the bedrock in the centre of Arctowski Icefield and the central part in the northwest direction, as can be inferred from the ice thickness (Fig. 6). The bedrock topography shows a high variability, directly visible in the ice-free regions of the island with high blocks and volcanic deposits.

The currently compiled bedrock topography reflects the general situation described by Birkenmajer (1997). The geology is roughly divided into an elevated unit called Barton Horst and a lower area named Fildes Block. The area surveyed in 1997 comprises parts of both units, while the area surveyed in 2007 is that of Barton Horst. There is no evidence of the geological features proposed by Birkenmajer (1997) (e.g. thrusts and faults) from the bedrock topography data, but these could be smoothed by the ice-bedrock interaction.

\section{CONCLUSIONS AND OUTLOOK}

The main domes and uncrevassed ice fields of KGI have been thoroughly surveyed by DGPS and GPR, resulting in a detailed surface and bed geometry. The high-frequency GPR data were migrated, and scattering features were interpreted to determine the thermal regime of the ice cap.

Prominent glaciological features visible in the GPR data are isochrones, most likely to be the result of volcanic ash. These indicate Raymond bumps in the vicinity of and below ice divides. Percolation of meltwater takes place all over the accumulation area. A water table has therefore developed over the ice cap, marking the transition of firn to ice at an average depth of $35 \mathrm{~m}$ in the higher parts. The presence of water is indicated by abundant internal radar diffraction signatures in the lower parts of the investigated area. These observations lead to the conclusion that the ice cap of KGI is temperate, at least in areas with surface elevations below $400 \mathrm{~m}$. According to radar backscatter interpretation, a cold core could still exist below the higher parts of the island.

Surface topography, thermal regime and ice flow of the ice cap may change during the next few decades. The dataset presented in this paper will provide a reference for future monitoring of the effects of climate change on the ice cap. The ice temperatures affect the flow regime of the ice cap considerably. The thermal conditions must be taken into account for 3-D diagnostic and prognostic full-Stokes numerical ice-flow modelling (see Rückamp and others, 2010).

\section{ACKNOWLEDGEMENTS}

We gratefully acknowledge financial support from the German Research Foundation (DFG) for the field campaigns of 1997 (DFG contract SA694-1/1), 2004/05 (DFG contracts BR2105/4-1/2/3) and 2007-09 (DFG contracts BL307-1/2) and respective evaluation periods. The 1997 fieldwork was funded by the Brazilian National Council for Scientific and Technological Development (CNPq) under project No. 480728/968. We also appreciate the logistic support provided by the Alfred Wegener Institute for Marine and
Polar Research (AWI), Germany, the Brazilian Navy, Instituto Antártico Argentino (IAA), Instituto Antártico Chileno (INACH) and Instituto Antártico Uruguayo (IAU). Special thanks are due to A. Lluberas (IAU) and the crews of Artigas and Bellingshausen stations. We also thank two anonymous reviewers for valuable comments.

\section{REFERENCES}

Birkenmajer, K. 1997. Geology of the northern coast of King George Island, South Shetland Islands (West Antarctica). Studia Geol. Polon., 110, 7-26.

Blindow, N. 1994. The central part of the Filchner-Ronne Ice Shelf, Antarctica: internal structures revealed by $40 \mathrm{MHz}$ monopulse RES. Ann. Glaciol., 20, 365-371.

Blindow, N. and F. Thyssen. 1986. Ice thickness and inner structure of the Vernagtferner (Ötztal Alps): results of electromagnetic reflection measurements. Z. Gletscherkd. Glazialgeol., 22(1), 43-60.

Braun, M. and R. Hock. 2004. Spatially distributed surface energy balance and ablation modelling on the ice cap of King George Island (Antarctica). Global Planet. Change, 42, 45-58.

Braun, M., H. Saurer, S. Vogt, J.C. Simões and H. Gossmann. 2001. The influence of large-scale atmospheric circulation on surface energy balance of the King George Island ice cap. Int. J. Climatol., 21(1), 21-36.

Braun, M., H. Saurer and H. Gossmann. 2004. Climate, energy fluxes and ablation rates on the ice cap of King George Island. Pesqui. Antárt. Brasil., 4, 87-103.

Eibert, T.F., V. Hansen and N. Blindow. 1997. Full-wave 3D-modeling of ground-penetrating radars by a finite element/boundary-element hybrid technique. In Stein, T.I., ed. IGARSS '97, 17th International Geoscience and Remote Sensing Symposium, 3-8 August, Singapore. Proceedings, Vol. 1. Piscataway, NJ, Institute of Electrical and Electronics Engineers, 227-229.

Eisen, O., A. Bauder, M. Lüthi, P. Riesen and M. Funk. 2009 Deducing the thermal structure in the tongue of Gornergletscher, Switzerland, from radar surveys and borehole measurements. Ann. Glaciol., 50(51), 63-70.

Govorukha, L.S., V.I. Chudakov and A.V. Shalygin. 1975. Radar ice sounding on King George (Waterloo) Island. Sov. Antarct. Exped. Inf. Bull., 8(11), 588-590.

Macheret, Yu.Ya. and M.Yu. Moskalevsky. 1999. Study of Lange Glacier on King George Island, Antarctica. Ann. Glaciol., 29, 202-206.

Paterson, W.S.B. 1994. The physics of glaciers. Third edition. Oxford, etc., Elsevier.

Peters, L., Jr. and J.D. Young. 1986. Applications of subsurface transient radar. In Miller, E.K., ed. Time-domain measurements in electromagnetics. New York, Van Nostrand Reinhold, 296-351.

Raymond, C.F. 1983. Deformation in the vicinity of ice divides. J. Glaciol., 29(103), 357-373.

Rückamp, M., N. Blindow, S. Suckro, M. Braun and A. Humbert. 2010. Dynamics of the ice cap on King George Island, Antarctica: field measurements and numerical simulations. Ann. Glaciol., 51(55), (see paper in this issue).

Simões, J.C. and U.F. Bremer. 1995. Investigation of King George Island ice cover using ERS-1 SAR and SPOT imagery. Rev. SELPER, 11(1-2), 56-60.

Simões, J.C., U.F. Bremer, F.E. Aquino and F.A. Ferron. 1999. Morphology and variations of glacial drainage basins in the King George Island ice field, Antarctica. Ann. Glaciol., 29, 220-224.

Simões, J.C. and 6 others. 2004. Ice core study from the King George Island, South Shetlands, Antarctica. Pesqui. Antárt. Brasil., 4, 9-23. 
Travassos, J.M. and J.C. Simões. 2004. High-resolution radar mapping of internal layers of a subpolar ice cap, King George Island, Antarctica. Pesqui. Antárt. Brasil., 4, 57-65.

Turner, J. and 8 others. 2005. Antarctic climate change during the last 50 years. Int. J. Climatol., 25, 279-294.
Wen, J., J. Kang, J. Han, Z. Xie, L. Liu and D. Wang. 1998. Glaciological studies on the King George Island ice cap, South Shetland Islands, Antarctica. Ann. Glaciol., 27, 105-109.

$\mathrm{Wu}, \mathrm{T}$. and R. King. 1965. The cylindrical antenna with nonreflecting resistive loading. IEEE Trans. Antennas Propag., 13(3), 369-373. 